This PDF is a selection from an out-of-print volume from the National Bureau of Economic Research

Volume Title: International Taxation and Multinational Activity

Volume Author/Editor: James R. Hines, Jr.

Volume Publisher: University of Chicago Press

Volume ISBN: 0-226-34173-9

Volume URL: http://www.nber.org/books/hine00-1

Conference Date: November 14-15, 1997

Publication Date: January 2000

Chapter Title: Tax Sparing and Direct Investment in Developing Countries

Chapter Author: James R. Hines Jr.

Chapter URL: http://www.nber.org/chapters/c10719

Chapter pages in book: (p. 39 - 72) 


\title{
Tax Sparing and Direct Investment in Developing Countries
}

\author{
James R. Hines Jr.
}

\subsection{Introduction}

Only a small fraction of the world's foreign direct investment (FDI) is located in developing countries. In 1990, countries that were not members of the OECD received roughly 15 percent of the $\$ 200$ billion of world FDI. Since these developing countries account for 35 percent of world GDP in 1990 (and 80 percent of the world's population), they received a much smaller fraction of total FDI than even their relatively modest economic activity levels appear to warrant. Numerous explanations have been advanced to account for the unwillingness of investors to locate FDI in the developing world, explanations that typically focus on distances to final markets, the difficulty or cost of obtaining important factors of production, inhospitable legal and regulatory environments, and the relatively undeveloped state of public infrastructure such as roads, port facilities, and telecommunications. ${ }^{1}$ Although the large number of available explanations can make it difficult to identify the most important determinants of FDI, many explanations share the feature that poor local economic conditions discourage FDI that might otherwise contribute to local economic development.

James R. Hines Jr. is professor of business economics at the University of Michigan Business School and a research associate of the National Bureau of Economic Research.

The author thanks Austin Nichols for outstanding research assistance, Hisahiro Naito and David Weinstein for expert advice concerning Japanese data, Timothy Goodspeed for helpful comments on an earlier draft, and the NBER for financial support.

1. See, e.g., Calvo, Leiderman, and Reinhart (1996), who note that the share of world FDI received by developing countries has risen since 1990. Data reported by the United Nations $(1997,303)$ indicate that the developing countries received 18 percent of world FDI flows over the 1985-90 period, and close to 35 percent of world FDI flows over the 1991-95 period. 
High-income countries are generally eager to promote economic development in low-income parts of the world. With that goal (and others) in mind, they often provide special fiscal incentives for their own firms to do business in developing countries. This paper examines the effect of the most common of these incentives, the provision of "tax sparing" credits.

"Tax sparing" is a practice designed to promote the effectiveness of local tax incentives for foreign investment. Developing countries are often willing to provide foreign investors significant fiscal incentives in order to encourage FDI and thereby stimulate local economic growth. Popular incentives include lengthy tax holidays, expensing or other generous tax treatment of new investment expenditures, and other tax reductions, as well as providing roads, worker training, and other public inputs at belowmarket prices. Tax incentives have the ability to stimulate foreign investment effectively and efficiently. Home-country tax systems may, however, reduce - or in some cases completely remove - incentives created by hostcountry tax abatements through corresponding increases in home-country tax burdens.

As an example, a multinational firm headquartered in a home country (such as the United States or Japan) that operates a residence-based worldwide tax system and grants foreign tax credits may find that tax reductions offered as investment incentives by host countries are exactly offset by higher home-country taxes. The reason is that host-country tax reductions imply that the firm can claim fewer foreign tax credits against home-country tax obligations.

In reaction to this possibility, many governments provide tax sparing credits for investments in developing countries. Tax sparing is the practice by which capital-exporting countries amend their taxation of foreign source income to allow firms to retain the advantages of tax reductions provided by host countries. Specifically, tax sparing often takes the form of allowing firms to claim foreign tax credits against home-country tax liabilities for taxes that would have been paid to foreign governments, in the absence of special abatements, on income from investments in certain developing countries. Since foreign tax credits are then based on tax obligations calculated without regard to taxes actually paid, any special tax breaks offered by host-country governments enhance the after-tax profitability of foreign investors and are not simply offset by higher homecountry taxes.

The practice of granting tax sparing credits is controversial, coming under fire from critics who claim that tax sparing credits are ineffective in encouraging greater investment in developing countries. ${ }^{2}$ The purpose of this paper is to evaluate this claim. Specifically, the paper compares patterns of Japanese and U.S. FDI over the same time period. Japan permits

2. See, e.g., the arguments advanced in OECD (1998). 
its firms to claim tax sparing credits for investments in certain developing countries, while the United States does not. Holding other considerations constant, it follows that, to the extent that tax sparing is effective, Japanese firms will exhibit greater willingness than U.S. firms to invest in developing countries. In addition, Japanese firms are more likely than U.S. firms to receive special tax breaks from countries with whom Japan has tax sparing agreements.

The results indicate that tax sparing is effective in stimulating FDI. Japanese firms locate a much higher fraction of their foreign investment in countries with whom Japan has tax sparing agreements than do U.S. firms. Furthermore, host governments appear to grant Japanese firms significant tax reductions that are not available to their U.S. counterparts. All other things being equal, tax sparing agreements are associated with 140-240 percent higher FDI levels and 23 percent lower tax rates on FDI.

Since Japan does not randomly assign tax sparing agreements to developing countries, one interpretation of the FDI evidence is that low-income countries with whom Japan has significant economic relations due to geographic proximity or cultural connections are those with whom Japan, in turn, decides to sign tax sparing agreements. In order to evaluate this interpretation, the regressions are rerun using, as an instrument for Japanese tax sparing, the existence of a tax sparing agreement between the United Kingdom and the country in question. The United Kingdom has a tax system very similar to Japan's and is likewise a major capital exporter that grants tax sparing for investments in a large number of developing countries - but the United Kingdom's geographical and cultural connections differ from Japan's. The results obtained using U.K. tax sparing agreements as instruments for Japanese tax sparing agreements are very similar to those generated by the ordinary least squares (OLS) regressions that take Japanese tax sparing to be exogenous.

These results are consistent with a growing body of recent evidence that tax systems influence the volume and location of FDI. Much of this evidence concerns the activity of U.S. firms, or of foreign firms investing in the United States, so it is useful to compare the behavior of U.S. firms to that of firms from a country, such as Japan, that has an otherwise similar tax system that differs in one important respect (tax sparing). The results are particularly impressive in light of the fact that host countries with whom Japan has tax sparing agreements face incentives to substitute tax incentives for nontax investment incentives they would otherwise offer Japanese firms. Since nontax investment incentives are difficult to verify and impossible to quantify, they are omitted from the regressions; so, to the degree that such incentives influence investment patterns, there is likely to be a bias against finding an important effect of tax sparing on the volume of FDI.

Section 2.2 of the paper reviews the tax treatment of foreign investment 
income and evidence of the impact of taxation on FDI patterns. Section 2.3 presents a model of the effect of tax sparing on FDI when host governments provide tax and nontax inducements to foreign investors. Section 2.3 also describes the data used in the empirical analysis. Section 2.4 presents the regression results. Section 2.5 is the conclusion.

\subsection{Taxation and Foreign Direct Investment}

In order to appreciate the likely effect of Japanese willingness (and U.S. reluctance) to grant tax sparing for investments in developing countries, it is useful first to review important aspects of the Japanese and U.S. systems of taxing foreign source income. ${ }^{3}$ This review is greatly simplified by the strong similarities between the two tax systems. This section considers the likely implications of tax sparing given existing evidence of the effect of taxation on the volume and location of FDI.

\subsubsection{Japanese and U.S. Taxation of FDI}

Both Japan and the United States tax income on a residence basis, meaning that corporations and individuals owe taxes to their home governments on all of their worldwide incomes, whether earned at home or abroad. In order to avoid subjecting multinationals to double taxation, Japan and the United States permit firms to claim foreign tax credits for income taxes (and related taxes) paid to foreign governments. ${ }^{4}$ The U.S. corporate tax rate is currently 35 percent. Under the foreign tax credit system, a U.S. corporation that earns $\$ 100$ in a foreign country with a 15 percent tax rate pays a tax of $\$ 15$ to the foreign government and $\$ 20$ to the U.S. government, since its U.S. corporate tax liability of $\$ 35$ (35 percent of $\$ 100$ ) is reduced to $\$ 20$ by the foreign tax credit of $\$ 15$.

\section{Tax Deferral}

Under both Japanese and U.S. law, firms must pay taxes to home governments on their worldwide incomes, with the exception that a certain category of foreign income is temporarily excluded from home-country taxation. The excluded category is the unrepatriated portion of the profits earned by foreign subsidiaries; taxpayers are permitted to defer any homecountry tax liability on those profits until they are paid as dividends to

3. Portions of the following brief description of U.S. law are excerpted from Hines (1991, 1997) and Hines and Hubbard (1995).

4. Japan and the United States are not alone in taxing the worldwide income of their resident companies while permitting firms to claim foreign tax credits. Other countries with such systems include Greece, Italy, Norway, and the United Kingdom. Under Japanese and U.S. law, firms may claim foreign tax credits for taxes paid by foreign affiliates of which they own at least 10 percent, and only those taxes that qualify as income taxes are creditable. 
parent firms resident in Japan or the United States. ${ }^{5}$ This deferral is available only on the active business profits of foreign affiliates that are separately incorporated as subsidiaries in foreign countries. The profits of unincorporated foreign businesses, such as those of Japanese or U.S. branch banks in other countries, are taxed immediately by their home governments.

To illustrate deferral, consider the case of a foreign subsidiary of a U.S. firm that earns $\$ 200$ in a foreign country without corporate taxes. This subsidiary might remit $\$ 50$ in dividends to its parent U.S. company, using the remaining $\$ 150$ to reinvest in its own, foreign, operations. The U.S. parent firm must then pay U.S. taxes on the $\$ 50$ of dividends it receives, but is not required to pay U.S. taxes on any part of the $\$ 150$ that the subsidiary earns abroad and does not remit to its parent company. If, however, the subsidiary were to pay a dividend of $\$ 150$ the following year, the firm would then be required to pay U.S. tax on that amount. Japanese, and to a greater extent, American, laws restrict the ability of firms to avoid home-country taxes by delaying the repatriation of lightly taxed foreign earnings. American laws do so by recharacterizing income from passive investments, conduit income, and funds reinvested in home countries as "deemed distributed" and therefore immediately taxable by home governments. Japanese laws do so with rules restricting the ability of subsidiaries to defer home taxation of profits earned in foreign tax havens.

\section{Excess Foreign Tax Credits}

The Japanese and U.S. governments permit firms to claim foreign tax credits, doing so with the understanding that these policies reduce tax collections on any given amount of foreign source income. The foreign tax credit is intended to reduce the problems created by international double taxation, since, in the absence of some kind of correction, the combined burdens of host-country and home-country taxation might effectively prohibit most international business transactions. Consequently, governments design their foreign tax credit systems to prevent firms from using foreign tax credits to reduce home-country tax liabilities that arise from profits earned within home countries.

There are limits on the foreign tax credits that Japanese and U.S. firms may claim; a firm's foreign tax credit limit equals the home-country tax liability generated by its foreign source income. For example, with a U.S. tax rate of 35 percent, an American firm with $\$ 200$ in foreign income faces a foreign tax credit limit of $\$ 70$ (35 percent of $\$ 200)$. If the firm paid foreign income taxes of less than $\$ 70$, then the firm would be entitled to claim

5. Deferral of home-country taxation of the unrepatriated profits of foreign subsidiaries is a common feature of systems that tax foreign incomes. Other countries that permit this kind of deferral include Canada, Denmark, France, Germany, Norway, Pakistan, and the United Kingdom. 
foreign tax credits for all of its foreign taxes paid. If, however, the firm paid $\$ 95$ in foreign taxes, it would be permitted to claim no more than $\$ 70$ in foreign tax credits.

Firms described by this second case, in which foreign tax payments exceed the foreign tax credit limit, are said to have "excess foreign tax credits"; the excess foreign tax credits represent the portion of foreign tax payments exceeding home-country tax liabilities generated by foreign incomes. Firms described by the first case, in which foreign tax payments are smaller than the foreign tax credit limit, are said to have "deficit foreign tax credits." Under Japanese and U.S. law, firms may use excess foreign tax credits in one year to reduce their tax obligations in other years. Japanese firms are allowed to apply any excess foreign tax credits against their Japanese tax obligations in the three previous years or in any of the following three years; American firms are allowed to apply any excess foreign tax credits against U.S. tax obligations in the two previous years or in any of the following five years. Foreign tax credits are not adjusted for inflation when applied against tax obligations in other years.

In practice, the calculation of the foreign tax credit limit entails many complications not reviewed here. One is that Japanese and U.S. laws require firms to use all of their worldwide foreign incomes to calculate foreign tax credit limits. Firms then have excess foreign tax credits if their worldwide foreign income tax payments exceed this limit. ${ }^{6}$ This procedure is known as "worldwide averaging."

\section{Tax Sparing}

The term "tax sparing" denotes the practice of amending home-country taxation in a way that permits investors to receive the full benefits of tax reductions by host countries. Many high-income capital-exporting countries, including Australia, Canada, France, Germany, Italy, Japan, the Netherlands, Norway, Sweden, Switzerland, and the United Kingdom, offer one form or another of tax sparing for investments in certain developing countries. ${ }^{7}$ In the cases of Japan and the United Kingdom, who have tax systems very similar to that of the United States, tax sparing typically takes the form of permitting firms to claim foreign tax credits for foreign

6. Not all countries that grant foreign tax credits use worldwide averaging. For example, the United Kingdom instead requires its firms to calculate foreign tax credits on an activityby-activity basis. The United States at one time required firms to calculate separate foreign tax credit limits for each country to whom taxes were paid; the current system of worldwide averaging was introduced in the mid-1970s.

7. For a survey of tax sparing practices, see OECD (1998). As the OECD report notes, tax sparing is an issue for countries that routinely exempt most foreign income from taxation, since certain categories of passive foreign income are generally not exempt from homecountry taxation. Furthermore, countries that ordinarily exempt foreign income from taxation usually apply antiavoidance regimes that subject foreign income to taxation (while granting foreign tax credits) if the foreign income is very lightly taxed by host governments. 
taxes that would be paid in the absence of special tax abatements. As a result, the benefits of any host-country tax abatements are not offset by reductions in the foreign tax credits that investors can claim against homecountry tax liabilities. This consideration is important to the extent that firms have deficit foreign tax credits and would incur significant costs in deferring repatriation of foreign profits to years in which there would be no associated home-country tax liability. ${ }^{8}$

Japan and the United Kingdom grant tax sparing credits through the terms of bilateral treaties with low-income countries. The Japanese government explains that it grants such credits in order to maintain the ability of developing countries to use fiscal incentives to attract Japanese FDI. ${ }^{9}$

The United States has been unwilling to grant tax sparing in any of its bilateral tax treaties, though the issue has arisen on numerous occasions. The most visible episode took place in 1957, when the United States signed a treaty with Pakistan providing that the United States would grant tax sparing credits for American investments in Pakistan. At the time, Pakistan granted tax concessions to qualifying enterprises making new investments in certain industries. Under the terms of the treaty, American investors in Pakistan would be entitled to claim foreign tax credits for the taxes they would have paid to Pakistan absent the special concessions granted by the Pakistani law.

U.S. tax treaties are not legally binding unless and until ratified by the U.S. Senate. After extensive hearings and deliberations, and amid considerable controversy, ${ }^{10}$ the U.S. Senate ratified the Pakistan treaty, but in so doing struck from the treaty its tax sparing provision. In subsequent treaties over the following forty-three years the United States has been unwilling to provide tax sparing for investments in any country. ${ }^{11}$ In opposing

8. See Hartman (1985), Sinn (1993), and Hines (1994) for analyses of the incentives created by foreign tax credits and deferral of home-country taxation. For evidence of the effect of home-country taxation on dividend repatriations, see Hines and Hubbard (1990), Altshuler and Newlon (1993), and Altshuler, Newlon, and Randolph (1995).

9. "Many developing countries have introduced various tax incentives in order to attract investment from abroad. Without the tax-sparing credit system, even if such tax incentive exempts Japanese investors from tax in a foreign country, they are taxed on worldwide income in Japan and the spared amount will only be transferred from the treasury of the developing country to that of Japan through smaller foreign tax credits allowed in Japan. The result is that no tax benefits remain in the hands of the investors. Therefore, the tax-sparing credit system does not annul the effect of tax incentives adopted by developing countries" (Japanese Ministry of Finance 1996, 122).

10. See U.S. Senate (1957). For samples of the ensuing controversy, see Crockett (1958) and Surrey (1958).

11. As Tillinghast (1996) notes, the Senate persists in rejecting not only treaties with tax sparing provisions but also those with creative alternatives. The signed, but unratified, 1967 Brazil-U.S. treaty contained a clause granting U.S. investors an investment tax credit, for investments in Brazil, that would be used to reduce U.S. tax liabilities on foreign source income. A similar type of investment tax credit was then available for domestic investments in the United States. The Senate refused to ratify the treaty with the investment tax credit provision. American intransigence concerning tax sparing is further illustrated by the fact 
ratification of the Pakistan treaty, Surrey (1958) argued that provision of tax sparing for investments in Pakistan would pressure the United States to provide tax sparing in all of its treaties with developing countries, ${ }^{12}$ and that such concessions are unwise and excessively costly. Furthermore, the Pakistan treaty raised fears of encouraging FDI at the expense of investment in the United States.

\subsubsection{Effect of Taxation on FDI}

During the deliberations over Senate ratification of the Pakistan treaty, Stanley Surrey (1958) could confidently assert that there was no reliable evidence that tax-based incentives, such as those created by tax sparing provisions, were likely to influence the pattern of FDI. That is an appropriate summary of the quantitative literature as it existed at the time. Now, more than forty years later, there is a considerable body of evidence, much of it recent, that documents a sizable effect of tax policies on the location and volume of FDI. Consequently, it is reasonable to expect tax sparing provisions to encourage direct investment and to affect host-country policies toward foreign investors.

Evidence of the effect of taxation on FDI comes in a variety of forms. Time series studies generally find FDI levels to respond positively to available after-tax rates of return, ${ }^{13}$ and cross-sectional studies of the location of outbound investment and the incentives facing different investors report consistently large effects of taxes. ${ }^{14}$ There is additional evidence of the ability of parent companies to adjust the financing of their foreign affiliates and the transfer prices used in transactions between related parties in response to tax differences, which may contribute to the appeal of locating FDI in low-tax locations. ${ }^{15}$ While this evidence varies in quality and in persuasiveness, taken as a whole it suggests that tax sparing is likely to influence significantly the location and experience of FDI.

\subsection{Tax Sparing and Foreign Direct Investment}

This section analyzes the effect of tax sparing on incentives for host governments to provide tax abatements, and nontax investment incentives,

that, of the twenty OECD members with tax treaties with China, the United States is alone in not granting tax sparing credits ( $\mathrm{Li} 1995)$.

12. True to this prediction, subsequent diplomatic notes with several developing countries (including China, India, and Thailand) bind the United States to provide tax sparing credits for investments in those countries if it ever grants tax sparing for investments anywhere else.

13. See, e.g., Hartman (1984), Boskin and Gale (1987), Newlon (1987), Young (1988), Slemrod (1990), and Swenson (1994).

14. See Grubert and Mutti (1991), Harris (1993), Hines and Rice (1994), Hines (1996), Devereux and Griffith (1998), and Desai and Hines (1999).

15. See Hines $(1997,1999)$ for interpretive surveys of this evidence and of the FDI literature. 
to foreign investors. This is followed by a review of the available data concerning foreign direct investment by Japanese and U.S. firms.

\subsubsection{Behavior of Host Governments}

Tax sparing agreements encourage FDI if foreign investors receive special tax abatements from host governments that would otherwise be offset by home-country taxes. For the same reason, host governments are considerably more likely to offer special tax abatements to foreign investors if their home governments grant tax sparing. In turn, tax abatements reduce the value of attracting additional FDI, and thereby make host governments somewhat less willing to provide nontax inducements for FDI. This section analyzes a simple model that formalizes these notions.

Consider the behavior of a government that maximizes $\Psi$, defined as

$$
\Psi \equiv B(I)+\tau Q(I, G)-c G,
$$

in which $I$ denotes the level of inbound FDI and $Q(I, G)$ is local profitability of that investment. Inbound FDI is taxed at rate $\tau$, so $\tau Q(I, G)$ is the local government's tax revenue from FDI. $B(I)$ denotes the nontax benefits of FDI to the local economy, measured in tax revenue equivalent units. $G$ is the level of public services provided by local governments to enhance a country's attractiveness to foreign investors, and $c$ is the per-unit cost of providing such services. ${ }^{16}$

The level of foreign investment is a function of various country characteristics and two variables under the government's control: the tax rate, $\tau$, and the level of public services, $G$. Investment can be written as $I\left(\tau^{*}, G\right)$, in which $\tau^{*}$ is the combined host- and home-country effective rate of profit taxation, itself a function of $\tau$. The first-order conditions characterizing interior solutions to the maximization of $\Psi$ over the choices of $\tau$ and $G$ are

$$
\begin{gathered}
{\left[B^{\prime}(I)+\tau \frac{\partial Q}{\partial I}\right] \frac{\partial I}{\partial \tau^{*}} \frac{\partial \tau^{*}}{\partial \tau}=-Q(I, G),} \\
{\left[B^{\prime}(I)+\tau \frac{\partial Q}{\partial I}\right] \frac{\partial I}{\partial G}=c-\tau \frac{\partial Q}{\partial G} .}
\end{gathered}
$$

Since $\tau^{*}$ is the combined level of home- and host-country taxation, it can be represented as

$$
\tau^{*}=\tau+\gamma\left[\tau^{\mathrm{h}}-\tau(1-\alpha)-\tau^{\mathrm{f}} \alpha\right],
$$

16. It is important that $c$ is the net cost of providing public services to attract FDI. For example, a government-provided road might simultaneously enhance the productivity of foreign capital and offer valuable services to local travelers. In such a case, $c$ is appropriately calculated as the cost of the road net of the monetary benefits of enhanced local travel (the numeraire taken to be the value of tax revenue). 
in which $\tau^{\mathrm{h}}$ is the home-country tax rate and $\tau^{\mathrm{f}}$ is the foreign tax rate in the absence of special abatements. The parameter $\gamma$ reflects the importance of home-country taxation: $\gamma=0$ if firms are effectively exempt from homecountry taxation (either because they have excess foreign tax credits or because they have opportunities for costless and indefinite deferral), while $\gamma=1$ if firms pay home-country taxes on any differences between domestic and foreign tax rates. In a sample of U.S. multinational firms, the average value of $\gamma$ is likely to be strictly bounded by 0 and 1 . The parameter $\alpha$ denotes tax sparing; $\alpha=1$ if the home country grants tax sparing, and $\alpha=0$ if not.

Differentiating equation (4),

$$
\frac{\partial \tau^{*}}{\partial \tau}=1-\gamma(1-\alpha)
$$

which reflects that tax sparing is relevant only insofar as the home country taxes foreign profits.

Equation (5) illuminates the effect of tax sparing on tax rate choices by host governments, because taking tax sparing to be a continuous rather than a discrete event, equation (5) implies that $\left(\partial^{2} \tau^{*}\right) /(\partial \tau \partial \alpha)=\gamma$. Tax sparing increases the sensitivity of total tax burdens to host-country tax rates. This, in turn, implies that tax sparing is likely to encourage host countries to offer foreign investors special tax reductions. From equation (2), it is clear that, absent a large effect of tax sparing on investment (ignoring any induced changes in $\tau$ ), tax sparing must be associated with reduced homecountry tax rates. Consider, for example, the case in which a host government does not offer any special tax abatements and the home government suddenly grants tax sparing. If $\tau$ does not change, then tax sparing has no effect on $I$, because tax sparing credits are available only for special tax reductions. But as long as $\gamma>0$, the introduction of tax sparing raises the value of $\partial \tau^{*} / \partial \tau$, so if equation (2) characterizes the host government's taxation of foreign investors prior to the introduction of tax sparing, it cannot continue to do so once the home government grants tax sparingunless $\tau$ falls.

Tax-sparing induced lower rates of home-country taxation are likely to be accompanied by reduced provision of government services valued by foreign investors. Lower rates of $\tau$ reduce the size of the bracketed term on the left side of equation (3) and increase the size of the expression on the right side of that equation, thereby implying that $\partial I / \partial G$ must rise in response. Since, under normal circumstances, $\partial I / \partial G$ is a decreasing function of $G$, it follows that tax sparing is associated with lower levels of government spending. Tax sparing encourages host governments to reduce $\tau$, thereby lowering the value to host governments of any additional $I$ triggered by higher levels of $G$. Put differently, tax sparing encourages host governments to substitute tax for nontax investment incentives. 


\subsubsection{Data}

The model implies that tax sparing encourages FDI in two ways: by reducing home-country taxation of foreign source income, and by encouraging host governments to offer special tax abatements to foreign investors. Existing Japanese and U.S. data are sufficient (if just barely) to test the investment and tax rate implications of the model. To a certain degree, the investment incentives created by tax sparing agreements will be offset by a tendency to substitute tax for nontax methods of encouraging investment by multinational firms based in countries granting tax sparing. However, because the willingness of many capital-exporting countries to grant tax sparing also encourages host countries to increase their default corporate tax rates, there are likely to be large differences between the tax rates paid by Japanese and U.S. firms, and significant differences in their investment patterns as a result.

The United Nations (1993) reports accumulated stocks of outbound FDI by Japanese and U.S. firms. Stock figures are denominated in U.S. dollars, and are distinguished by location for a large sample of countries. Foreign direct investment stocks consist of accumulated debt and equity investment from parent companies plus reinvested profits of foreign affiliates. Japanese and U.S. FDI stocks are book figures, which makes them sensitive to inflation and therefore no better than proxies for market values of FDI. Japanese and U.S. shares of total FDI stocks are, in principle, comparable, but since the estimation sample excludes FDI in Japan and the United States, mean values of Japanese and U.S. FDI will differ in a systematic way. ${ }^{17}$ Data on GDP are taken from the Summers-Heston database (Summers and Heston 1991). Table 2.1 presents means and standard deviations of variables used in the regressions.

Data on the foreign activities of U.S. firms are collected by the U.S. Department of Commerce Bureau of Economic Analysis (BEA), which performs periodic benchmark surveys of the foreign operations of U.S. multinational corporations. ${ }^{18}$ U.S. Department of Commerce (1992) contains income and balance sheet information for 1989 for foreign affiliates owned at least 10 percent by U.S. parents. The BEA reports aggregate figures for countries in which there is substantial U.S. investment; to protect the confidentiality of survey respondents, BEA suppresses information for coun-

17. In 1990, 42 percent of the Japanese FDI stock was located in the United States, while 5 percent of the U.S. FDI stock was located in Japan. By omitting data on FDI in Japan and the United States from the sample, the mean share of U.S. FDI is certain to exceed the mean share of Japanese FDI.

18. American firms with foreign affiliates and assets exceeding $\$ 3$ million are obliged to respond to the BEA survey; BEA estimates that its survey respondents have 99.6 percent of the foreign assets of U.S. firms. The regression variables are constructed from BEA data on the activities of nonbank affiliates of nonbank parent firms. The BEA data are the basis of FDI studies by Grubert and Mutti (1991), Hines and Rice (1994), and Desai and Hines (1999), from which some of the following descriptive material is drawn. 
Table 2.1

Means and Standard Deviations of Regression Variables

\begin{tabular}{|c|c|c|c|}
\hline Variable & Mean & $\begin{array}{l}\text { Standard } \\
\text { Deviation }\end{array}$ & $N$ \\
\hline \multicolumn{4}{|c|}{ A. FDI Sample (Tables 2.3, 2.5) } \\
\hline Japan FDI share minus U.S. FDI share & -0.005269 & 0.023243 & 67 \\
\hline Tax sparing & 0.22388 & 0.41999 & 67 \\
\hline $\ln (\mathrm{GDP})$ & 18.0559 & 1.6787 & 67 \\
\hline Tax sparing $\times \ln (\mathrm{GDP})$ & 3.9464 & 7.7661 & 67 \\
\hline \multicolumn{4}{|c|}{ B. Tax Rate Sample (Table 2.7) } \\
\hline Japan tax rate minus U.S. tax rate & 0.08548 & 0.22381 & 18 \\
\hline Tax sparing & 0.44444 & 0.51131 & 18 \\
\hline $\ln (G D P)$ & 19.7114 & 1.0179 & 18 \\
\hline Tax sparing $\times \ln (\mathrm{GDP})$ & 7.5464 & 9.7638 & 18 \\
\hline \multicolumn{4}{|c|}{ C. Equity Investment Sample (Tables 2.9, 2.10) } \\
\hline Japan equity share minus U.S. equity share & -0.002896 & 0.021906 & 19 \\
\hline Tax sparing & 0.42105 & 0.50726 & 19 \\
\hline $\ln (\mathrm{GDP})$ & 19.6060 & 1.0907 & 19 \\
\hline Tax sparing $\times \ln (\mathrm{GDP})$ & 7.1492 & 9.6454 & 19 \\
\hline
\end{tabular}

Note: The table presents means and standard deviations of variables used in the regressions. Foreign direct investment shares are ratios of FDI stocks in 1990 to total stocks of outbound FDI by source countries. Tax rates are ratios of income taxes paid in 1989 to total pretax income. Equity investment shares are ratios of stocks of paid-in equity in 1989 to total foreign equity investment stocks of source countries. "Tax sparing" is a dummy variable that equals 1 if Japan grants tax sparing and 0 otherwise.

tries in which one or two U.S. firms represent large fractions of total U.S. investment.

The BEA reports amounts of paid-in affiliate equity, as well as the pretax incomes and income tax payments of U.S. firms. It is therefore possible to construct an average income tax rate that equals the ratio of income taxes paid by local affiliates of U.S. firms to their local pretax incomes. Such a calculation is based on aggregates, and may therefore overstate tax rates by including information on affiliates with tax losses. Nevertheless, it is a reliable indicator of the use of tax preferences such as special deductions, depreciation rules, carryforwards and carrybacks, tax holidays, and nonstandard income concepts.

Data on the foreign business activities of Japanese firms come from annual surveys conducted by the Japanese Ministry of International Trade and Industry (MITI), which cover foreign operations in which parent firms hold at least 10 percent ownership stakes. Firms are not obliged to respond to these surveys, and while most do, the response rate is far from 100 percent. ${ }^{19}$ Responses to the 1989 survey, tabulated in MITI (1991), constitute the Japanese data used in the empirical work.

19. For example, in the 1991 survey, MITI sent questionnaires to 3,368 companies, of which 1,789 responded. While Japanese firms with extensive foreign operations are perhaps 
The MITI reports aggregate information for Japanese affiliates in order to preserve the confidentiality of survey respondents, but it distinguishes some items by location of affiliate and industry of parent company. The MITI data include information on the paid-in equity of parent Japanese firms, the "ordinary income" of affiliates, and affiliates' after-tax profits. The Japanese translation of "paid-in equity" is "capital stock," but this balance sheet entry excludes retained earnings and is therefore comparable to the American notion of paid-in equity.

"Ordinary income" is a Japanese accounting concept that equals the difference between income items (such as net sales revenue and capital income) and expense items (including interest charges and depreciation). "After-tax profits" equal "ordinary income" plus net extraordinary gains, plus net disposition of special reserves, minus corporate taxes. It is possible, therefore, to use the difference between ordinary income and aftertax profits as an indicator of the corporate tax burden facing Japanese affiliates, though this entails ignoring the (typically small) differences introduced by extraordinary gains and the disposition of special reserves. ${ }^{20}$ More likely to be problematic are systematic differences between Japanese and U.S. accounting conventions, making levels of Japanese and U.S. tax burdens (thereby calculated) not exactly comparable. Consequently, the empirical work focuses on differences between average tax rates paid by Japanese firms in countries with whom Japan does and does not have tax sparing agreements, contrasting these with differences in tax rates paid by U.S. firms.

\subsection{Evidence from U.S. and Japanese Firms}

This section evaluates evidence of the impact of tax sparing agreements appearing in differences between the location and performance of foreign investment by U.S. and Japanese firms.

\subsubsection{FDI in a Large Cross Section}

Japanese investors exhibit a pronounced tendency to locate FDI in countries with whom Japan has tax sparing agreements. Table 2.2 presents a simple comparison of Japanese and U.S. investment patterns. Of the sixty-seven receiving countries for whom FDI data are available, Japan has tax sparing agreements with fourteen. The Japanese share of FDI located in a country is defined to be $\left(\mathrm{FDI}_{\mathrm{i}} / \mathrm{FDI}_{\mathrm{tot}}\right)$, in which $\mathrm{FDI}_{\mathrm{i}}$ is the stock

more likely than others to respond to the MITI questionnaire, there is no way of verifying this directly.

20. The calculations constrain tax rates facing Japanese and U.S. firms to lie between 0 and 100 percent. Calculated tax rates omit consideration of taxes other than income taxes, since firms are eligible to claim foreign tax credits only for income taxes paid to foreign governments. 
Table 2.2

FDI Shares

\begin{tabular}{lll}
\hline & Japan & United States \\
\hline Tax sparing $(N=14)$ & & \\
$\quad$ Median (\%) & 0.601 & 0.358 \\
$\quad$ Mean & 0.942 & 0.715 \\
$\quad$ Standard deviation & 1.06 & 0.988 \\
No tax sparing $(N=53)$ & & \\
$\quad$ Median (\%) & 0.0219 & 0.124 \\
Mean & 0.604 & 1.38 \\
Standard deviation & 1.54 & 3.29 \\
\hline
\end{tabular}

Note: The table presents medians, means, and standard deviations of Japanese and U.S. FDI shares in two groups of countries in 1990: those with whom Japan has tax sparing agreements (fourteen countries), and those with whom Japan does not have tax sparing agreements (fiftythree countries). Entries are percentages. Foreign direct investment shares are ratios of FDI stocks in 1990 to total stocks of outbound FDI by source countries. Median FDI shares are observations with median values in each cell.

of Japanese FDI located in country i in 1990, and FDI ${ }_{\text {tot }}$ is the stock of Japanese FDI located in all countries in 1990. American FDI shares for 1990 are defined analogously. The median Japanese FDI share in the fourteen countries with whom Japan has tax sparing agreements is 0.60 percent and the mean Japanese FDI share is 0.94 percent, both of which exceed the median ( 0.36 percent) and mean ( 0.72 percent) U.S. FDI shares in the same countries.

It is useful to confirm that these differences are not merely functions of Japanese and U.S. investment patterns in countries excluded from the sample (particularly the United States and Japan), so the second row of table 2.2 presents investment share information for the fifty-three sample countries with whom Japan does not have tax sparing agreements. Investment patterns in these countries differ markedly from those with whom Japan has tax sparing agreements. The median Japanese FDI share in this subsample is 0.02 percent and the mean share is 0.64 percent, while the U.S. FDI share has a median of 0.12 percent and a mean of 1.38 percent.

Figure 2.1 illustrates the comparison between Japanese and U.S. investment patterns. The black bars in the figure represent mean shares of Japanese investment, and the white bars mean shares of U.S. investment. The two bars on the left describe investment shares in countries with whom Japan does not have tax sparing agreements, whereas the two bars on the right describe investment shares in countries with whom Japan does have tax sparing agreements.

These differences can be compared in a straightforward way in a regression context. The first column of table 2.3 presents estimated coefficients from regressing differences between Japanese and U.S. FDI shares in each of the sample countries on a constant term and a dummy variable that 


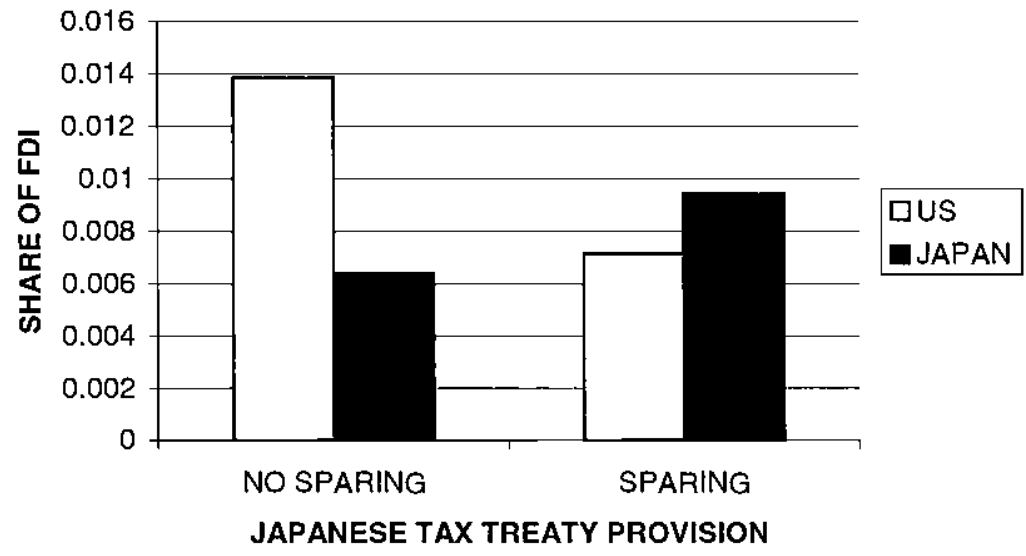

\section{Fig. 2.1 Tax sparing and FDI}

Note: The figure presents mean FDI shares of U.S. and Japanese firms. Foreign direct investment shares are ratios of FDI stocks in 1990 to total stocks of outbound FDI by source countries. White bars depict average FDI shares of U.S. firms, and black bars depict average FDI shares of Japanese firms. The two bars on the left describe FDI shares in countries with whom Japan does not have tax sparing agreements, whereas the two bars on the right describe FDI shares in countries with whom Japan does have tax sparing agreements.

Table 2.3

FDI Shares and Tax Sparing

Dependent Variable:

Japanese FDI Share Minus U.S. FDI Share

(1)

(2)

(3)

\begin{tabular}{lccc}
\hline Constant & -0.007445 & 0.097620 & 0.097485 \\
& $(0.003538)$ & $(0.037801)$ & $(0.037076)$ \\
Tax sparing & 0.009719 & 0.016805 & \\
& $(0.004517)$ & $(0.006756)$ & \\
$\ln ($ GDP $)$ & & -0.005907 & -0.005894 \\
& & $(0.002266)$ & $(0.002220)$ \\
Tax sparing $\times \ln ($ GDP $)$ & & & 0.0009296 \\
& & 0.196 & $0.0003494)$ \\
$R^{2}$ & 0.031 & 67 & 0.201 \\
$N$ & 67 & 67 \\
\hline
\end{tabular}

Note: The dependent variable is the difference between Japanese and U.S. shares of their respective total FDI stocks in 1990. "Tax sparing" is a dummy variable that equals 1 if Japan grants tax sparing and 0 otherwise. The table presents estimated coefficients from OLS regressions; heteroskedasticity-consistent standard errors are in parentheses. 
equals 1 if Japan has a tax sparing agreement, and equals 0 otherwise. The estimated coefficient on the dummy variable, 0.0097, indicates that differences between Japanese and U.S. FDI shares are roughly 1 percent higher in countries with whom Japan has tax sparing agreements than they are in other countries. The regression reported in column (2) of table 2.3 indicates that the effect of tax sparing on Japanese U.S. FDI share differences rises with the inclusion of $\ln (\mathrm{GDP})$ as an explanatory variable, the estimated coefficient on the dummy variable implying that Japanese FDI shares are roughly 1.7 percent higher in countries with whom Japan has tax sparing agreements. The third column of table 2.3 reports the results of a regression specification in which the tax sparing dummy variable is interacted with $\ln (\mathrm{GDP})$; again, tax sparing is associated in a significant way with higher FDI levels. Evaluated at the mean of $\ln (\mathrm{GDP})$, the coefficient implies that tax sparing agreements coincide with 1.7 percent higher Japanese FDI shares. Since the Japanese FDI share has a sample mean of 0.71 percent, effects in the range of $0.97-1.7$ percent correspond to FDI that is 1.4-2.4 times greater than what it would have been in the absence of tax sparing.

Japan does not grant tax sparing on a random basis, thereby raising the possibility that the observed correlation between FDI and tax sparing reflects the influence of variables omitted from the FDI equation. Countries with whom Japan has close economic or cultural ties are likely to receive unusually large fractions of Japanese FDI and might also be countries with whom Japan is inclined to conclude tax sparing agreements. Given the arbitrariness of most methods of identifying the closeness of bilateral relations with Japan, it can be difficult to distinguish the effect of tax sparing on Japanese FDI from the effect of other connections that are correlated with the presence of tax sparing agreements.

An alternative method is to use tax sparing agreements between the United Kingdom and various developing countries as instruments for tax sparing agreements that involve Japan. The United Kingdom is a major capital exporter, has a tax system that resembles Japan's, and is similarly inclined to include tax sparing provisions in its bilateral treaties with developing countries. The advantage of using U.K. tax sparing provisions as proxies for Japanese provisions is that the United Kingdom has economic and cultural ties that differ from Japan's, and U.K. tax treaty patterns are therefore less likely to be influenced by important variables that are omitted from the Japanese FDI equation. Table 2.4 presents information on the countries with whom Japan and the United Kingdom had tax sparing arrangements as of 1990. Both countries exhibit a tendency to offer tax sparing for investments in major developing countries, but there are some differences between their country coverages.

Table 2.5 presents instrumental variables (IV) estimates of the FDI equations reported in table 2.2 , with a $0-1$ dummy variable indicating the 


\begin{tabular}{|c|c|c|c|c|c|}
\hline Country & Japan & $\begin{array}{l}\text { United } \\
\text { Kingdom }\end{array}$ & Country & Japan & $\begin{array}{c}\text { United } \\
\text { Kingdom }\end{array}$ \\
\hline Argentina & No & $\mathrm{No}^{\mathrm{a}}$ & Malaysia $^{\mathrm{b}}$ & SP & SP \\
\hline Australia ${ }^{b}$ & No & No & Mauritania & No & No \\
\hline Austria & No & No & Mauritius & No & $\mathrm{SP}$ \\
\hline Bangladesh & SP & SP & Mexico $^{\mathrm{b}}$ & $\mathrm{No}^{\mathrm{a}}$ & $\mathrm{No}^{\mathrm{a}}$ \\
\hline Bolivia & No & No & Morocco & No & $\mathrm{SP}$ \\
\hline Brazil $^{\mathrm{b}}$ & SP & No & Netherlands ${ }^{\mathrm{b}}$ & No & No \\
\hline Cameroon & No & No & New Zealand ${ }^{\mathrm{c}}$ & No & No \\
\hline Canada $^{\mathrm{b}}$ & No & No & Nigeria & No & SP \\
\hline Chile & No & No & Norway & No & No \\
\hline China $^{b}$ & SP & SP & Pakistan & SP & SP \\
\hline Colombia & No & No & Panama & No & No \\
\hline Costa Rica & No & No & Papua New Guinea & No & SP \\
\hline Cyprus & No & SP & Paraguay & No & No \\
\hline Denmark & No & No & Peru & No & No \\
\hline Dominican Republic & No & No & Philippines ${ }^{\mathrm{b}}$ & SP & No \\
\hline Ecuador & No & No & Poland & No & No \\
\hline Egypt & No & SP & Portugal & No & SP \\
\hline Finland & No & No & Senegal & No & No \\
\hline France $^{\mathrm{b}}$ & No & No & Singapore $^{\mathrm{b}}$ & SP & SP \\
\hline Gabon & No & No & South Africa & No & No \\
\hline West Germany ${ }^{\mathrm{b}}$ & No & No & Spain $^{\mathrm{b}}$ & SP & SP \\
\hline Ghana & No & SP & Sri Lanka & SP & SP \\
\hline Greece & No & No & Sweden & No & No \\
\hline Guyana & No & $\mathrm{No}^{\mathrm{a}}$ & Switzerland ${ }^{\mathrm{b}}$ & No & No \\
\hline Hong Kong ${ }^{\mathrm{b}}$ & No & n.a. & Thailand & SP & SP \\
\hline India & SP & SP & Trinidad \& Tobago & No & SP \\
\hline Indonesia $^{\mathrm{b}}$ & SP & SP & Tunisia & No & SP \\
\hline Iran & No & No & Turkey & $\mathrm{No}^{\mathrm{a}}$ & SP \\
\hline Ireland & SP & No & United Kingdom $^{\mathrm{b}}$ & No & n.a. \\
\hline Israel & No & SP & Uruguay & No & No \\
\hline Italy ${ }^{\mathrm{b}}$ & No & No & Venezuela & No & $\mathrm{No}^{\mathrm{a}}$ \\
\hline Jamaica & No & SP & Zambia & SP & SP \\
\hline Kenya & No & SP & Zimbabwe & No & No \\
\hline Korea, Republic of ${ }^{b}$ & SP & SP & & & \\
\hline
\end{tabular}

Note: The table consists of the sixty-seven countries for whom FDI and GDP data are available for 1990. Entries in the first column indicate whether Japan grants tax sparing in 1990, and in the second column, whether the United Kingdom does so. SP = tax sparing; No = no tax sparing; n.a. = not applicable (governments do not have treaties with themselves).

${ }^{a}$ Denotes countries with tax sparing agreements subsequent to 1990.

${ }^{\mathrm{b}}$ Denotes observations included in the eighteen- and nineteen-country samples analyzed in tables 2.62.10 .

${ }^{\mathrm{c}}$ Denotes the observation (New Zealand) included in the nineteen-country sample analyzed in tables 2.9 and 2.10. 
Table 2.5

FDI Shares and Tax Sparing, IV Specification

Dependent Variable:

Japanese FDI Share Minus U.S. FDI Share

\begin{tabular}{lccc}
\cline { 2 - 4 } & $(1)$ & $(2)$ & $(3)$ \\
\hline Constant & -0.012186 & 0.112725 & 0.116498 \\
& $(0.005503)$ & $(0.040895)$ & $(0.041754)$ \\
Tax sparing & 0.030895 & 0.030150 & \\
$\ln ($ GDP $)$ & $(0.013881)$ & $(0.012128)$ & -0.0071516 \\
Tax sparing $\times \ln ($ GDP $)$ & & -0.006909 & $(0.0025396)$ \\
$N$ & & $(0.002482)$ & $(0.0018653$ \\
& & & $(0.0007268)$ \\
& 67 & 67 & 67 \\
\hline
\end{tabular}

Note: The dependent variable is the difference between Japanese and U.S. shares of their respective total FDI stocks in 1990. "Tax sparing" is a dummy variable that equals 1 if Japan grants tax sparing and 0 otherwise. The table presents estimated coefficients from instrumental variables regressions in which U.K. tax sparing agreements are used as instruments for Japanese tax sparing agreements. Heteroskedasticity-consistent standard errors are in parentheses.

presence of a U.K. tax sparing agreement serving as an instrument for Japanese tax sparing agreements. (The first stage equations of these IV estimates are specified as linear probability models.) The results are somewhat more dramatic than those reported in Table 2.3: the estimated effect of Japanese tax sparing remains significant, and is now on the order of 3 percent differences in FDI shares.

\subsubsection{Tax Sparing and Tax Rates}

The model analyzed and described in section 2.3 implies that foreign investors are likely to receive fiscal inducements in the form of reduced taxes in situations in which home countries grant tax sparing credits. This section compares the experiences of Japanese and U.S. firms in order to test this implication of the model.

Table 2.6 distinguishes the average tax rates faced by Japanese and U.S. firms in sample countries with whom Japan has tax sparing agreements and those with whom Japan does not have tax sparing agreements. Aggregate tax burdens are quite consistent with the model's implications. In the seven countries in the sample with whom Japan has tax sparing agreements, Japanese firms face average tax rates of 28 percent, as compared with 32 percent for U.S. firms. Sample medians differ more widely: The average Japanese tax rate in the median country is 23 percent, while the average U.S. tax rate in the median country is 39 percent.

Comparison of the average foreign tax burdens of U.S. and Japanese firms can be highly problematic due both to differences in their tax treat- 
Tax Rates

\begin{tabular}{lcc}
\hline & Japan & United States \\
\hline Tax sparing $(N=7)$ & & \\
Median (\%) & 22.5 & 38.5 \\
Mean & 27.7 & 32.2 \\
Standard deviation & 2.02 & 18.9 \\
No tax sparing $(N=11)$ & & \\
Median (\%) & 52.6 & 35.8 \\
Mean & 48.3 & 29.4 \\
Standard deviation & 26.5 & 12.2 \\
\hline
\end{tabular}

Note: The table presents medians, means, and standard deviations of Japanese and U.S. average tax rates in two groups of countries in 1989: those with whom Japan has tax sparing agreements (seven countries), and those with whom Japan does not have tax sparing agreements (eleven countries). Entries are percentages. Tax rates are ratios of income taxes paid in 1989 to total pretax income. Median tax rates are observations with median values in each cell.

ments by host governments and to differences in national accounting conventions. The most useful way to frame the tax rate information reported in the first row of table 2.6 is to contrast it with evidence of average tax rates faced by U.S. and Japanese firms in other countries. The second row of table 2.6 reports this information, which suggests that, in countries with whom Japan does not have tax sparing agreements, Japanese firms report significantly higher average tax rates than do U.S. firms. The average foreign tax rate faced by Japanese firms in sample countries with whom Japan does not have a tax sparing agreement is 48 percent, while the corresponding average tax rate faced by U.S. firms is 29 percent. Median tax rates are 53 percent and 36 percent, respectively. These data suggest that some combination of national accounting practices, differences in the ways that foreign affiliates are financed, and other business practices that enable firms to avoid local taxes, tend to elevate the calculated tax rates faced by Japanese firms compared to their American counterparts. These differences make more striking the evidence of lower tax rates faced by Japanese firms in countries with whom Japan has tax sparing agreements.

Figure 2.2 presents these differences graphically. The black bars in the figure represent average tax rates paid by Japanese firms, and the white bars average tax rates paid by U.S. firms. The two left-most bars describe tax rates in countries with whom Japan does not have tax sparing agreements, whereas the two right-most bars describe tax rates in countries with whom Japan does have tax sparing agreements.

Table 2.7 presents estimates of the effect of tax sparing on average tax rate differences. The OLS estimates in column (1) confirm that the differences apparent in table 2.6 are statistically significant: A tax sparing agreement with Japan is associated with Japanese tax rates that are 23 percent lower than those faced by U.S. firms. Although the small sample 


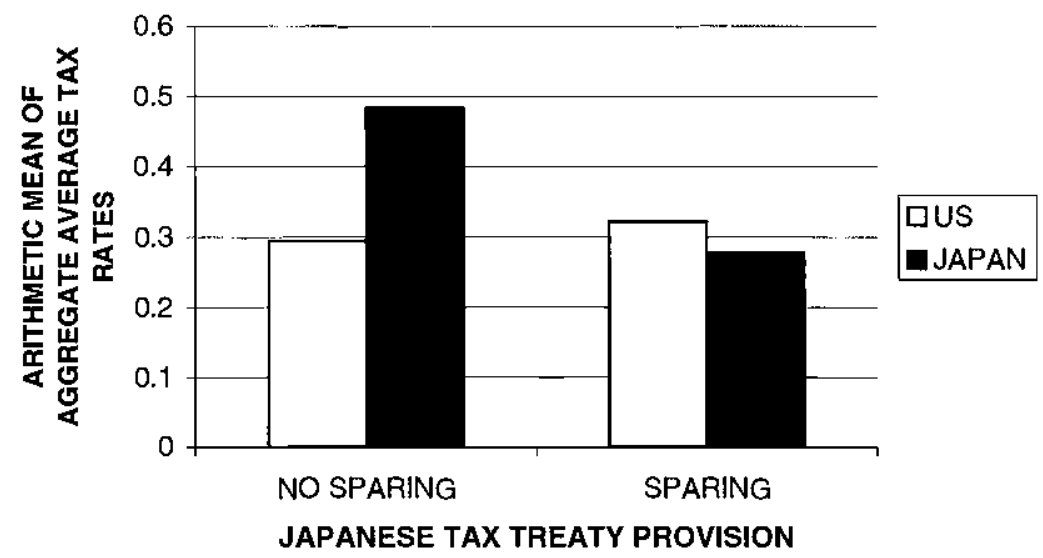

Fig. 2.2 Average tax rates

Note: The figure presents average tax rates paid by U.S. and Japanese firms. Tax rates are ratios of income taxes paid in 1989 to total pretax income. White bars depict average tax rates paid by U.S. firms, and black bars depict average tax rates paid by Japanese firms. The two bars on the left describe tax rates in countries with whom Japan does not have tax sparing agreements, whereas the two bars on the right describe tax rates in countries with whom Japan does have tax sparing agreements.

Table 2.7

Tax Rates and Tax Sparing

Dependent Variable:

Japanese Tax Rate Minus U.S. Tax Rate

\begin{tabular}{lcccc}
\cline { 2 - 5 } & OLS & OLS & IV & IV \\
\hline Constant & 0.18962 & -0.43658 & 0.14474 & -0.71477 \\
& 0.05954 & $(0.86044)$ & $(0.07305)$ & $(0.73381)$ \\
Tax sparing & -0.23430 & -0.22076 & -0.13332 & -0.11314 \\
& $(0.09320)$ & $(0.09608)$ & $(0.11885)$ & $(0.11744)$ \\
$\ln ($ GDP) & & 0.03146 & & 0.04315 \\
& & $(0.04330)$ & & $(0.03781)$ \\
$R^{2}$ & 0.287 & 0.306 & & 18 \\
$N$ & 18 & 18 & 18 & 18 \\
\hline
\end{tabular}

Note: The dependent variable is the difference between host-country tax rates facing Japanese and U.S. firms in 1989. Tax rates are ratios of income taxes paid in 1989 to total pretax income. "Tax sparing" is a dummy variable that equals 1 if Japan grants tax sparing and 0 otherwise. The first two columns present estimated coefficients from OLS regressions. The third and fourth columns present estimated coefficients from IV regressions in which U.K. tax sparing agreements are used as instruments for Japanese tax sparing agreements. Heteroskedasticity-consistent standard errors are in parentheses.

size (only eighteen observations) is unfortunate, it is worth bearing in mind that these eighteen countries receive 66 percent of Japanese FDI not bound for the United States. Inclusion of GDP as a regressor changes the results very little, as the results reported in column (2) indicate. Using the existence of a tax sparing agreement with the United Kingdom as an 
instrument for Japanese tax sparing reduces both the size and the statistical significance of the estimated effect of tax sparing, as indicated by the instrumental variables (IV) results reported in columns (3) and (4). Though the estimates continue to imply a large (13 percent) effect of tax sparing on tax rate differences between Japanese and U.S. firms, this difference is no longer significant in the IV regressions. At least in part, this is the product of using an IV procedure on such a small sample.

\subsubsection{Tax Sparing and Equity Investments}

From the evidence reported in section 2.4.1 it is clear that Japanese firms are more inclined than are U.S. firms to locate FDI in countries with whom Japan has tax sparing agreements. Foreign direct investment equals equity and debt flows from parent firms plus the reinvested profits of local affiliates. Tax sparing agreements will, therefore, encourage Japanese FDI even if the agreements affect only the reinvested profits of Japanese affiliates. Suppose that affiliates routinely reinvest a certain fraction of their after-tax profits; if tax sparing agreements prompt host governments to reduce local taxes, then affiliates' after-tax profits will rise and so will the retained earnings component of FDI. Consequently, the observed correlation between tax sparing agreements and FDI does not necessarily imply that tax sparing encourages equity investments. Because the determinants of equity capital flows are of independent interest, and because host countries are understandably eager to attract such flows, it is useful to consider the determinants of U.S.-Japanese differences in equity investments. In addition, the equity data come in a disaggregated form that distinguishes investments by industry of affiliate. As with the tax rate information, however, the data are available for only a rather small sample of countries.

Table 2.8 presents data on U.S. and Japanese shares of equity capital located in the nineteen sample countries for which such data are available.

Table 2.8

Equity Investment Shares

\begin{tabular}{lll}
\hline & Japan & United States \\
\hline Tax sparing $(N=7)$ & & \\
$\quad$ Median (\%) & 2.65 & 0.401 \\
Mean & 2.55 & 0.978 \\
Standard deviation & 1.27 & 1.32 \\
No tax sparing $(N=12)$ & & \\
Median $(\%)$ & 0.743 & 2.48 \\
Mean & 1.50 & 3.14 \\
Standard deviation & 1.54 & 2.70 \\
\hline
\end{tabular}

Note: The table presents medians, means, and standard deviations of Japanese and U.S. shares of equity investment in two groups of countries in 1989: those with whom Japan has tax sparing agreements (seven countries), and those with whom Japan does not have tax sparing agreements (twelve countries). Entries are percentages. Equity investment shares are ratios of stocks of paid-in equity in 1989 to total foreign equity investment stocks of source countries. Median investment shares are observations with median values in each cell. 


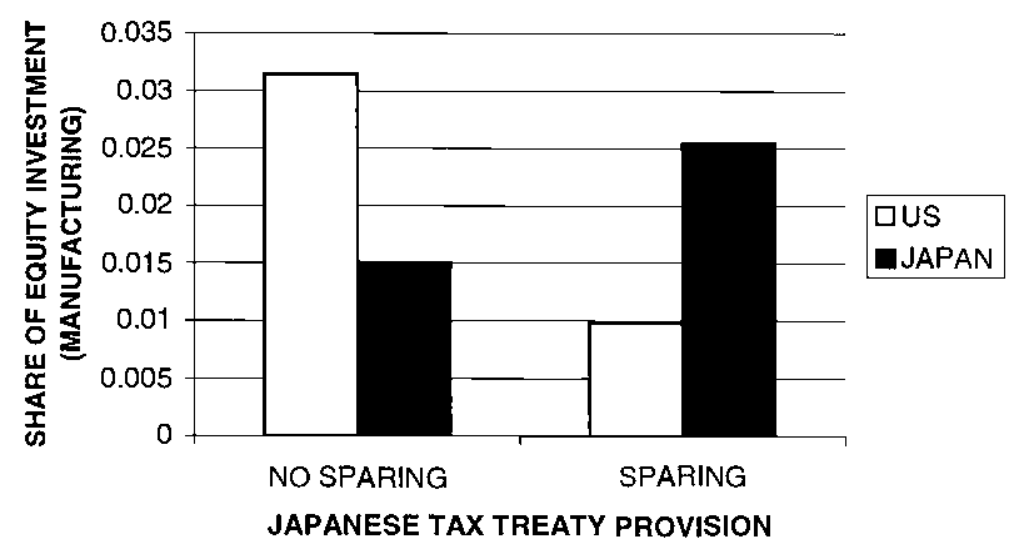

Fig. 2.3 Tax sparing and equity investment

Note: The figure presents mean equity investment shares of U.S. and Japanese firms in manufacturing industries. Equity investment shares are ratios of stocks of paid-in equity in 1989 to total foreign equity investment stocks of source countries. White bars depict average equity investment shares of U.S. firms, and black bars depict average equity investment shares of Japanese firms. The two bars on the left describe equity investment shares in countries with whom Japan does not have tax sparing agreements, whereas the two bars on the right describe equity investment shares in countries with whom Japan does have tax sparing agreements.

Data apply to firms in manufacturing industries only. ${ }^{21}$ Japanese firms locate an average of 2.6 percent of their foreign equity in the seven sample countries with whom Japan has tax sparing agreements, and 1.5 percent in the twelve countries without Japanese tax sparing agreements. By comparison, U.S. firms locate an average of 1 percent of their foreign equity in tax sparing countries and 3.1 percent in those with whom Japan does not have tax sparing agreements. Similarly signed and somewhat more dramatic differences appear between median equity investments of Japanese and U.S. firms. Figure 2.3 depicts the mean equity investment shares of Japanese (black bars) and U.S. (white bars) firms in countries with and without Japanese tax sparing agreements.

Table 2.9 analyzes these data in a regression context. In the regression reported in column (1), tax sparing is associated with a 3.2 percent difference between Japanese and U.S. shares of investment in the form of equity capital. The estimated effect of tax sparing is 3.1 percent when $\ln$ (GDP) is included as a regressor (as reported in column [2]), as it is when tax sparing is interacted with $\ln (\mathrm{GDP})$ (as reported in column [3]), and its effect evaluated at the mean value of $\ln (\mathrm{GDP})$. Evaluated at the mean Jap-

21. The sample is restricted to manufacturing industries in order to enhance the comparability of figures for Japanese and U.S. firms and to increase the available sample size. The results reported in tables $2.8-2.10$ are very similar to those obtained using data on firms in all industries. 


\begin{tabular}{lccc}
\hline & \multicolumn{3}{c}{$\begin{array}{c}\text { Dependent Variable: Japanese Equity Investment Share } \\
\text { Minus U.S. Equity Investment Share }\end{array}$} \\
\cline { 2 - 4 } & $(1)$ & $(2)$ & $(3)$ \\
\hline Constant & -0.016399 & 0.108494 & 0.115843 \\
& $(0.004706)$ & $(0.047536)$ & $(0.044455)$ \\
Tax sparing & 0.032069 & 0.030605 & \\
& $(0.006924)$ & $(0.006639)$ & -0.006616 \\
$\ln ($ GDP $)$ & & -0.006339 & $(0.002286)$ \\
Tax sparing $\times \ln ($ GDP $)$ & & $(0.002411)$ & 0.001534 \\
& & & $0.000368)$ \\
$R^{2}$ & 0.551 & 0.650 & 0.606 \\
$N$ & 19 & 19 & 19 \\
\hline
\end{tabular}

Note: The dependent variable is the difference between Japanese and U.S. equity investment shares in manufacturing industries in 1989. "Tax sparing" is a dummy variable that equals 1 if Japan grants tax sparing and 0 otherwise. The table presents estimated coefficients from OLS regressions; heteroskedasticity-consistent standard errors are in parentheses.

anese equity investment share of 1.9 percent, a 3.1 percent difference implies that tax sparing is associated with Japanese equity investments that are 1.6 times greater than they would have been in the absence of tax sparing.

Table 2.10 presents the results of IV regressions in which tax sparing agreements with the United Kingdom serve as instruments for Japanese tax sparing agreements. The results are quite similar to those reported in table 2.9, with the difference that the estimated effect of tax sparing on equity investment rises (e.g., to 4.1 percent in the regression reported in column [1]), and the estimated standard errors are somewhat larger as well.

Industry-level data on Japanese and U.S. equity investments are, in principle, available for numerous two-digit industries, but various omissions make it impossible to obtain even modest sample sizes for any but six manufacturing industries. The six two-digit industries for which it is possible to make meaningful comparisons of Japanese and U.S. equity investment shares are food products, chemicals, metal products, nonelectrical machinery, electric and electronic equipment, and transportation equipment. Table 2.11 presents results of six regressions in which differences between Japanese and U.S. equity investment shares are regressed on constants and a dummy variable indicating the presence of a Japanese tax sparing agreement. All of the estimated coefficients on the tax sparing dummy variable are positive; in three cases (chemicals, metal products, and electric and electronic equipment), they are significant at the 95 percent confidence level, and in two others (food products and transportation equipment), at the 90 percent confidence level. 
Dependent Variable: Japanese Equity Investment Share Minus U.S. Equity Investment Share

\begin{tabular}{lccc}
\cline { 2 - 4 } & $(1)$ & $(2)$ & $(3)$ \\
\hline Constant & -0.019994 & 0.096699 & 0.091997 \\
& $(0.005629)$ & $(0.059393)$ & $(0.078644)$ \\
Tax sparing & 0.040606 & 0.039028 & \\
& $(0.008303)$ & $(0.008551)$ & \\
$\ln ($ GDP $)$ & & -0.005918 & -0.0057752 \\
& & $(0.002958)$ & $(0.0039112)$ \\
Tax sparing $\times \ln ($ GDP $)$ & & & 0.0025648 \\
$N$ & 19 & 19 & $(0.0007048)$ \\
& & & 19 \\
\hline
\end{tabular}

Note: The dependent variable is the difference between Japanese and U.S. equity investment shares in manufacturing industries in 1989. "Tax sparing" is a dummy variable that equals 1 if Japan grants tax sparing and 0 otherwise. The table presents estimated coefficients from instrumental variables regressions in which U.K. tax sparing agreements are used as instruments for Japanese tax sparing agreements. Heteroskedasticity-consistent standard errors are in parentheses.

Table 2.11

Tax Sparing and Equity Investment by Industry

Dependent Variable: Japanese Equity Investment Share Minus U.S. Equity Investment Share

\begin{tabular}{lcccr}
\cline { 2 - 5 } Industry & Constant & Tax Sparing & $R^{2}$ & $N$ \\
\hline Food products & -0.046152 & 0.060704 & 0.337 & 10 \\
Chemicals & $(0.021636)$ & $(0.027808)$ & & \\
& -0.027949 & 0.059861 & 0.577 & 15 \\
Metal products & $(0.009784)$ & $(0.014118)$ & & \\
& -0.028922 & 0.071336 & 0.337 & 14 \\
Nonelectric machinery & $(0.015063)$ & $(0.029844)$ & & \\
& -0.008548 & 0.002025 & 0.002 & 11 \\
Electric equipment & $(0.009247)$ & $(0.010235)$ & & \\
& -0.035529 & 0.049279 & 0.739 & 8 \\
Transportation equipment & $(0.009245)$ & $(0.011971)$ & & \\
& -0.000949 & 0.018457 & 0.224 & 11 \\
\hline
\end{tabular}

Note: The dependent variables are differences between Japanese and U.S. equity investment shares in each of the six indicated two-digit manufacturing industries in 1989. "Tax Sparing" is a dummy variable that equals 1 if Japan grants tax sparing and 0 otherwise. The table presents estimated coefficients from OLS regressions; heteroskedasticity-consistent standard errors are in parentheses. 
While these results are, of course, consistent with all of the other available evidence of the effect of tax sparing on investment, the very small sample sizes make their interpretation for any particular industry quite difficult. What the results reported in table 2.11 do is to clarify that the tax sparing evidence available from aggregate data do not reflect obvious industrial differences between Japanese and U.S. investment patterns. Table 2.12 presents the results of industry-level regressions in which U.K. tax sparing agreements are used as instruments for Japanese tax sparing agreements. The estimated effects of tax sparing on equity investment are very similar to those reported in table 2.11 .

\subsubsection{Implications}

The regression results indicate that tax sparing agreements have sizable effects on the location and volume of FDI, and on the tax rates faced by foreign investors. These two effects are of course related, since hostcountry tax reductions encourage FDI, and host governments grant tax abatements in anticipation of attracting additional FDI. Estimates available in the literature (e.g., Hines and Rice 1994) suggest that tax rate reductions of 23 percent should stimulate roughly 80 percent greater FDI; but these estimates are based on the behavior of U.S. firms that are not entitled to claim tax sparing credits for host-country tax reductions. Tax

Table 2.12

Tax Sparing and Equity Investment by Industry, IV Specification

\begin{tabular}{lccc}
\hline & \multicolumn{2}{c}{$\begin{array}{c}\text { Dependent Variable: } \\
\text { Japanese Equity Investment Share } \\
\text { Minus U.S. Equity Investment Share }\end{array}$} \\
\cline { 2 - 4 } Industry & Constant & Tax Sparing & $N$ \\
\hline Food products & -0.043827 & 0.054889 & 10 \\
Chemicals & $(0.024629)$ & $(0.048381)$ & \\
Metal products & -0.028804 & 0.061465 & 15 \\
Nonelectric machinery & $(0.011315)$ & $(0.019402)$ & \multirow{2}{*}{14} \\
Electric equipment & -0.021615 & 0.045763 & \\
& $(0.018839)$ & $(0.023065)$ & 11 \\
Transportation equipment & -0.008548 & 0.002025 & 11 \\
& $-0.009247)$ & $(0.010235)$ & 8 \\
& $(0.0095245)$ & $\begin{array}{l}(0.011971) \\
0.023440\end{array}$ & 11 \\
& $(0.002761$ & $0.011714)$ & \\
\hline
\end{tabular}

Note: The dependent variables are differences between Japanese and U.S. equity investment shares in each of the six indicated two-digit manufacturing industries in 1989. "Tax Sparing" is a dummy variable that equals 1 if Japan grants tax sparing and 0 otherwise. The table presents estimated coefficients from instrumental variables regressions in which U.K. tax sparing agreements are used as instruments for Japanese tax sparing agreements. Heteroskedasticity-consistent standard errors are in parentheses. 
sparing increases, possibly manyfold, the sensitivity of FDI to hostcountry taxes. Consequently, the finding that tax sparing is associated with 140-240 percent greater FDI, or roughly double the effect that would have been predicted on the basis of tax rate differences and in the absence of tax sparing credits, is quite consistent with the earlier literature.

\subsection{Conclusion}

Most high-income capital-exporting countries, including Japan, provide tax sparing for investments in developing countries. The United States steadfastly refuses to do so, and Japanese and U.S. FDI experiences differ as a consequence. Japanese firms are significantly more likely than U.S. firms to concentrate their outbound FDI, and its equity component, in countries with whom Japan has tax sparing agreements. Host-government policies are also affected: Japanese firms are taxed at lower rates than are U.S. firms in countries with whom Japan has tax sparing agreements. These differences persist when tax sparing agreements with the United Kingdom are used as instruments for Japanese tax sparing agreements.

The argument that tax sparing is unlikely to influence FDI patterns is inconsistent with this evidence and with a larger literature that documents the effect of taxation on the activities of multinational firms. There is a more basic question, which this paper does not directly address, of the desirability of encouraging FDI in this way. In order to answer this question, it is necessary to evaluate not only the likely effects of tax sparing on levels of FDI and the policies of host governments, but also the effects of tax sparing on tax compliance and tax complexity, its impact on ongoing treaty negotiations, the effect of outbound FDI on domestic economic performance, and the desirability of enacting major tax provisions through treaties rather than tax legislation. For more than forty years, the U.S. Senate has held that these considerations (and possibly others) imply that it is not in the interest of the United States to grant tax sparing in any of its treaties. In practice, this position appears to be partly responsible for the relatively modest levels of American investment in developing countries.

\section{References}

Altshuler, Rosanne, and T. Scott Newlon. 1993. The effects of U.S. tax policy on the income repatriation patterns of U.S. multinational corporations. In Studies in international taxation, ed. Alberto Giovannini, R. Glenn Hubbard, and Joel Slemrod, 77-115. Chicago: University of Chicago Press.

Altshuler, Rosanne, T. Scott Newlon, and William C. Randolph. 1995. Do repatri- 
ation taxes matter? Evidence from the tax returns of U.S. multinationals. In The effects of taxation on multinational corporations, ed. Martin Feldstein, James R. Hines Jr., and R. Glenn Hubbard, 253-72. Chicago: University of Chicago Press.

Boskin, Michael, and William G. Gale. 1987. New results on the effects of tax policy on the international location of investment. In The effects of taxation on capital accumulation, ed. Martin Feldstein, 201-19. Chicago: University of Chicago Press.

Calvo, Guillermo A., Leonardo Leiderman, and Carmen M. Reinhart. 1996. Inflows of capital to developing countries. Journal of Economic Perspectives 10 (2): $123-39$.

Crockett, Joseph P. 1958. "Tax sparing": A legend finally reaches print. National Tax Journal 11 (2): 146-55.

Desai, Mihir A., and James R. Hines Jr. 1999. "Basket" cases: Tax incentives and international joint venture participation by American multinational firms. Journal of Public Economics 71 (3): 379-402.

Devereux, Michael P., and Rachel Griffith. 1998. Taxes and the location of production: Evidence from a panel of US multinationals. Journal of Public Economics 68 (3): 335-67.

Grubert, Harry, and John Mutti. 1991. Taxes, tariffs and transfer pricing in multinational corporate decision making. Review of Economics and Statistics 73 (2): 285-93.

Harris, David G. 1993. The impact of U.S. tax law revision on multinational corporations' capital location and income-shifting decisions. Journal of Accounting Research 31 (Suppl.): 111-40.

Hartman, David G. 1984. Tax policy and foreign direct investment in the United States. National Tax Journal 37 (4): 475-87.

. 1985. Tax policy and foreign direct investment. Journal of Public Economics 26 (1): 107-21.

Hines, James R., Jr. 1991. The flight paths of migratory corporations. Journal of Accounting, Auditing, and Finance 6 (4): 447-79.

1994. Credit and deferral as international investment incentives. Journal of Public Economics 55 (2): 323-47.

. 1996. Altered states: Taxes and the location of foreign direct investment in America. American Economic Review 86 (5): 1076-94.

. 1997. Tax policy and the activities of multinational corporations. In Fiscal policy: Lessons from economic research, ed. Alan J. Auerbach, 401-45. Cambridge, Mass.: MIT Press.

- 1999. Lessons from behavioral responses to international taxation. $\mathrm{Na}$ tional Tax Journal 52 (2): 305-22.

Hines, James R., Jr., and R. Glenn Hubbard. 1990. Coming home to America: Dividend repatriations by U.S. multinationals. In Taxation in the global economy, ed. Assaf Razin and Joel Slemrod, 161-200. Chicago: University of Chicago Press.

. 1995. Appendix. In Taxing multinational corporations, ed. Martin Feldstein, James R. Hines Jr., and R. Glenn Hubbard, 103-6. Chicago: University of Chicago Press.

Hines, James R., Jr., and Eric M. Rice. 1994. Fiscal paradise: Foreign tax havens and American business. Quarterly Journal of Economics 109 (1): 149-82.

Japanese Ministry of Finance. Tax Bureau. 1996. An outline of Japanese taxes, 1996. Tokyo: Japanese Ministry of Finance.

Japanese Ministry of International Trade and Industry (MITI). Industrial Policy Bureau, Multinational Firm Division. 1991. Kaigai toshi tokei soran (Compen- 
dium of foreign investment statistics). Tokyo: Ministry of Finance Printing Office.

Li, Jinyan. 1995. China's tax treaties and their impact on foreign investment. Tax Notes International 10 (23): 1891-1911.

Newlon, Timothy Scott. 1987. Tax policy and the multinational firm's financial policy and investment decisions. Ph.D. diss. Princeton University.

Organization for Economic Cooperation and Development (OECD). 1998. Tax sparing: A reconsideration. Paris: OECD.

Sinn, Hans-Werner. 1993. Taxation and the birth of foreign subsidiaries. In Trade, welfare and economic policies: Essays in honor of Murray C. Kemp, ed. Horst Herberg and Ngo Van Long, 325-52. Ann Arbor: University of Michigan Press.

Slemrod, Joel. 1990. Tax effects of foreign direct investment in the United States: Evidence from a cross-country comparison. In Taxation in the global economy, ed. Assaf Razin and Joel Slemrod, 79-117. Chicago: University of Chicago Press.

Summers, Robert, and Alan Heston. 1991. The Penn world table (mark 5): An expanded set of international comparisons. Quarterly Journal of Economics 106 (2): 327-68.

Surrey, Stanley S. 1958. The Pakistan tax treaty and "tax sparing." National Tax Journal 11 (2): 156-67.

Swenson, Deborah L. 1994. The impact of U.S. tax reform on foreign direct investment in the United States. Journal of Public Economics 54 (2): 243-66.

Tillinghast, David R. 1996. U.S. tax treaty issues. Tax Notes International 13 (8): $625-40$.

United Nations. 1993. World investment directory 1992: Foreign direct investment, legal framework and corporate data. Vol. 3. Developed countries. New York: United Nations.

United Nations. 1997. World investment report 1997: Transnational corporations, market structure, and competition policy. New York: United Nations.

U.S. Department of Commerce. Bureau of Economic Analysis. 1992. U.S. direct investment abroad: 1989 benchmark survey, final results. Washington, D.C.: GPO.

U.S. Senate Committee on Foreign Relations. 1957. Double taxation convention with Pakistan: Hearings before the Senate Committee on Foreign Relations. 85th Cong., 1st sess. Washington, D.C.: GPO.

Young, Kan H. 1988. The effects of taxes and rates of return on foreign direct investment into the United States. National Tax Journal 41 (1): 109-21.

\section{Comment Timothy J. Goodspeed}

Developing countries need to attract capital to grow. The importance of evaluating how developing countries can attract long-term foreign capital has always been important, but the question has become particularly relevant in light of the recent rapid outflows of short-term capital and the resulting volatility in capital markets in countries such as Mexico and South Korea. As we have witnessed, turmoil in global capital markets

Timothy J. Goodspeed is associate professor of economics at Hunter College and the City University of New York Graduate Center. 
affects the welfare of both developed and developing countries. Tax sparing is one fiscal tool that developed countries have at their disposal to help developing countries attract capital.

Developing countries consider a tax sparing provision to be an important element of tax treaties with developed country treaty partners that practice worldwide taxation and give a foreign tax credit. For, without a tax sparing provision, a developing country that tries to attract foreign investment by offering a reduced tax rate for a period of time (a tax holiday) will find that its policy is ineffective and simply transfers tax revenue to the developed country treaty partner. This is because a multinational based in the developed country that repatriates (or is deemed to repatriate) income from a subsidiary in the developing country (and that finds itself in a deficit foreign tax credit position) will owe tax to the developed country in the amount of the difference between the (reduced) taxes paid to the developing country and the taxes that would have been owed to the developed country had the income been earned there. Under a tax sparing provision, credit is normally calculated at the higher statutory rate rather than at the reduced rate of the tax holiday. The multinational is, in effect, given credit for taxes it did not actually pay, thereby preserving the intended incentive of the tax holiday.

The paper by James R. Hines Jr. addresses whether tax sparing is effective in attracting capital to developing countries. As readers of the literature in international taxation have come to expect from the author, he once again brings clever and impressive economic analysis to bear on an important but neglected aspect of international taxation. For U.S. policy makers, his empirical results may be surprising and somewhat disconcerting. As he indicates, the United States has historically refused to approve tax treaties that contain tax sparing provisions. While this is partly due to general tax principles, it also derives from the perception that tax sparing is ineffective in helping developing countries attract capital. If tax sparing is ineffective in stimulating new investment, it may simply provide a windfall to old capital. Hines finds that this perception is incorrect; he finds that tax sparing is effective in stimulating investment, including new equity investment, in developing countries. The study constitutes an important advance in our understanding of the effect of tax sparing on investment activities.

Hines goes about his task by comparing outbound investment patterns and foreign average tax rates of companies based in two countries, Japan and the United States, that both use a foreign tax credit system. Japan tends to grant tax sparing to developing countries while the United States does not. The evidence is presented in three parts. First, Hines examines whether the share of Japanese FDI in country. A relative to the share of U.S. FDI in country A depends on whether country A has a tax sparing agreement with Japan. Second, he examines whether the average tax rate 
faced by Japanese companies investing in country A relative to the average tax rate faced by American companies investing in country A depends on whether Japan has a tax sparing agreement with country A. Third, Hines tries to ascertain whether investment that is induced by tax sparing agreements is new equity investment or simply higher after-tax earnings resulting from, for instance, a tax holiday, that is reinvested.

The first part of the evidence presented uses United Nations data on FDI by Japanese and U.S. multinationals in sixty-seven countries. A dummy variable is used to indicate whether a country has a tax sparing agreement with Japan; Hines finds that the existence of a tax sparing agreement (controlling for GDP differences) has a positive and significant effect on the share of Japanese relative to U.S. investment. The second and third parts of the evidence presented use data on investment activities of Japanese multinationals published by the Japanese Ministry of International Trade and Industry (MITI) to construct average tax rates and measure new equity investment of Japanese multinationals in eighteen countries. Corresponding variables for U.S. multinationals are constructed from data compiled by the Bureau of Economic Analysis (BEA). Hines finds that tax sparing is negatively and significantly associated with the difference between Japanese and U.S. tax rates in a country. He also finds that tax sparing is positively and significantly related to the difference between Japanese and U.S. equity investment shares. It is easy to criticize the regressions that use the MITI data for the small number of observations, but one must recognize that obtaining the Japanese data at all (and understanding Japanese accounting, not to mention the linguistic interpretations of accounting concepts) is a difficult problem that the author had to overcome. The use of this untapped data constitutes a valuable addition to our knowledge.

The biggest problem that Hines faces (and he recognizes this) is that there are many factors besides tax sparing that influence the difference in investment shares of U.S. and Japanese companies. In analyzing trade patterns, it is particularly important to note the proximity and historical ties of trading partners. What this means in the case of U.S. versus Japanese investment patterns is that one is likely to find a greater share of Japanese investment going to Asian trading partners. As it happens, many Japanese tax sparing agreements are with countries in Asia. The problem, then, is that one may find a positive correlation between countries with tax sparing agreements with Japan and Japan's share of investment relative to the U.S. share that is due to natural trading patterns rather than to tax sparing agreements.

This applies equally to the results on tax rates. Tax sparing can lead to lower tax rates for Japanese companies either directly or because of tax competition among similar countries. One possible reason for observing lower Japanese tax rates in the tax sparing countries is that these countries 
are in competition with other Asian countries. Again, since Japanese tax sparing agreements tend to be with Asian countries, it is not easy to separate out the effect that results from tax sparing and the effect that results from tax competition among Asian countries for Japanese investment.

One natural correction for this is to include a dummy variable for Asian countries, possibly augmented by more sophisticated spatial econometric techniques. This is difficult, however, because few non-Asian countries in Hines's sample have a tax sparing agreement with Japan. (The countries in this category are Brazil and Spain in the small sample; the UN data add Zambia and Ireland to the list.) Hines comes up with a clever alternative. He attempts to circumvent the problem by using the countries with which the United Kingdom has a tax sparing agreement as an instrument for a country that has a tax sparing agreement with Japan. The United Kingdom tends to have tax sparing agreements with most of the countries with Japanese tax sparing agreements (Ireland being one notable exception), and in addition, the United Kingdom has tax sparing agreements with several other African, Caribbean, and European countries. The instrumental variable approach tends to support the conclusion that tax sparing agreements are associated with higher Japanese relative to American shares of FDI.

A second factor apart from tax sparing that might influence the difference in investment shares of U.S. and Japanese companies is different laws in the two countries. For instance, although both the United States and Japan calculate the foreign tax credit on a worldwide basis (as Hines points out), the way in which the credit is calculated differs. The United States calculates its foreign tax credit limit using "baskets" to try to divide highly taxed and lowly taxed income. Japan, on the other hand, does not, and uses some other rules (described in Ault 1997) to try to limit averaging of foreign taxes. If it is easier for Japanese companies to average foreign taxes, there could be a greater incentive for Japanese companies to generate income in a low-tax country, thereby offsetting taxes paid in a high-tax country. This could lead to a high response of investment from tax sparing by Japan that would not be replicated by a U.S. tax sparing agreement. The tax sparing dummy could be partially picking up the difference between laws in the United States and those in Japan.

A third factor that might be influencing investment patterns are public good levels. Hines includes public expenditures as well as taxes in his theoretical model, and his inclusion of GDP as an explanatory factor may partly proxy for general demand for public goods. However, some disaggregation of demand for public goods may be called for if some countries provide more in the way of public goods that are valued by businesses. To the extent that U.S. and Japanese investment patterns are similar across industries, this should not matter much, because any bias introduced will be the same for both countries. However, it could matter if one country's 
FDI is skewed more toward industries that use public goods valued more intensively by businesses.

Finally, I would like to bring up some issues not directly addressed in the study that are important in determining whether tax sparing is desirable. First, there are many methods of encouraging capital accumulation and growth in developing countries. Tax sparing is but one method, and its advantages and disadvantages should be compared to those of other methods of encouraging investment. For example, what are the advantages and disadvantages of using tax sparing rather than direct aid to encourage investment? One problem with tax sparing is that it provides an incentive for a profitable company only. New start-up ventures that anticipate initial losses will have little additional incentive because there is no advantage for those who have no tax liability. Another problem with tax sparing is that it may encourage transfer pricing abuses. Hines reports that Japanese companies tend to report tax rates that are higher than for American companies in countries without a tax sparing agreement. Yet the data of Grubert, Goodspeed, and Swenson (1993) (GGS) indicate low rates of return (taxable income divided by assets) earned by Japanese companies in the United States. This raises the possibility that Japanese companies could be using transfer prices to funnel income earned in the United States through tax sparing countries. Since GGS find that at least half of the low taxes paid by Japanese companies in the United States can be explained by reasons other than transfer pricing, such pricing strategies may not be overly abusive; nevertheless, transfer pricing problems need to be evaluated in judging the efficacy of tax sparing. Direct aid avoids the possible transfer pricing problems of tax sparing, but has problems of its own, such as the need to set up a bureaucracy to administer grants and the lack of private market determination of which projects are financed.

A second issue that is important to understand that is not addressed in Hines's study is how tax sparing affects the timing of repatriation decisions. Suppose developing country A decides to offer a tax holiday; further suppose that the United States, for instance, changes its tax treaty with country A to allow tax sparing. Without the tax sparing provision, the reduced tax rate will be valuable only if income is not repatriated. With the tax sparing provision, income can be repatriated without further taxation. Hence, a U.S. multinational may have an incentive to repatriate income more rapidly than it would have otherwise. Such a reaction on the part of the U.S. multinational could lead to greater volatility in capital markets, rather than less.

All this is not meant to take away from the important contribution of the paper, which is the first serious effort to measure the effect of tax sparing on investment decisions. Moreover, the paper rather ingeniously gets the most out of the data by using an instrumental variables approach to address one of the problems just outlined - that of Japanese trade patterns 
with Asian countries apart from tax sparing provisions. Still, the data limitations lead one to conclude that the results of this paper are suggestive, but do not yet provide a definitive answer to the question of whether and by how much tax sparing affects investment activities. This, in turn, suggests that there remain a number of interesting ways in which future studies could advance research on tax sparing. Such studies will need to work with a somewhat broader data set. With such a data set, recent techniques developed using spatial econometric methods or fixed effects models could be implemented. Such studies would be a valuable addition, and could provide more assurance to policy makers who remain skeptical about the value of tax sparing.

\section{References}

Ault, Hugh. 1997. Comparative income taxation: A structural analysis. Boston: Kluwer Law International.

Grubert, Harry, Timothy J. Goodspeed, and Deborah Swenson. 1993. Explaining the low taxable income of foreign-controlled companies in the United States. In Studies in international taxation, ed. Alberto Giovannini, R. Glenn Hubbard, and Joel Slemrod, 237-70. Chicago: University of Chicago Press. 
